\title{
How and where do workers learn?
}

Citation for published version (APA):

van Eldert, P., Fouarge, D., de Grip, A., \& Poulissen, D. (2017). How and where do workers learn? ROA. ROA Fact Sheets No. 004E https://doi.org/10.26481/umarof.2017004E

Document status and date:

Published: 01/01/2017

DOI:

10.26481/umarof.2017004E

Document Version:

Publisher's PDF, also known as Version of record

\section{Please check the document version of this publication:}

- A submitted manuscript is the version of the article upon submission and before peer-review. There can be important differences between the submitted version and the official published version of record.

People interested in the research are advised to contact the author for the final version of the publication, or visit the DOI to the publisher's website.

- The final author version and the galley proof are versions of the publication after peer review.

- The final published version features the final layout of the paper including the volume, issue and page numbers.

Link to publication

\footnotetext{
General rights rights.

- You may freely distribute the URL identifying the publication in the public portal. please follow below link for the End User Agreement:

www.umlib.nl/taverne-license

Take down policy

If you believe that this document breaches copyright please contact us at:

repository@maastrichtuniversity.nl

providing details and we will investigate your claim.
}

Copyright and moral rights for the publications made accessible in the public portal are retained by the authors and/or other copyright owners and it is a condition of accessing publications that users recognise and abide by the legal requirements associated with these

- Users may download and print one copy of any publication from the public portal for the purpose of private study or research.

- You may not further distribute the material or use it for any profit-making activity or commercial gain

If the publication is distributed under the terms of Article $25 \mathrm{fa}$ of the Dutch Copyright Act, indicated by the "Taverne" license above, 


\section{How and where do workers learn?}

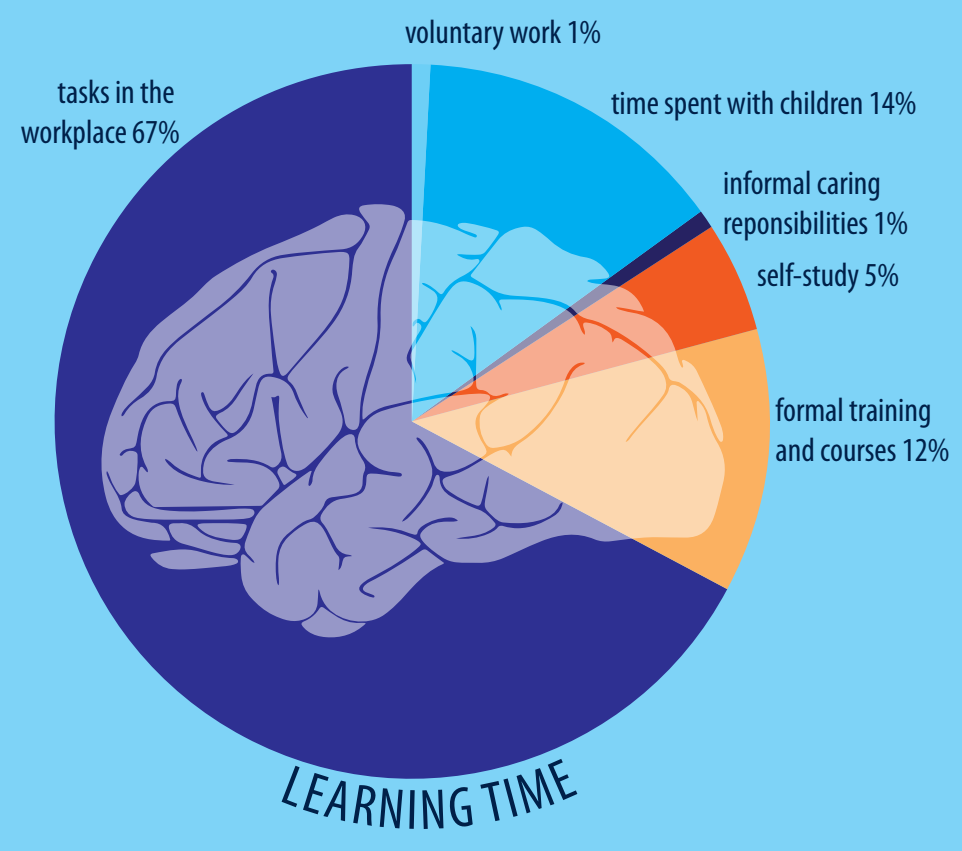

Source: ROA Lifelong Learning Survey 2017

\section{ROA Fact Sheet}

ROA-F-2017/4E

Researchcentrum voor Onderwijs en Arbeidsmarkt | ROA Research Centre For Education and the Labour Market / ROA 


\section{HOW AND WHERE DO WORKERS LEARN?}

: HOW DO YOU LEARN AT WORK?

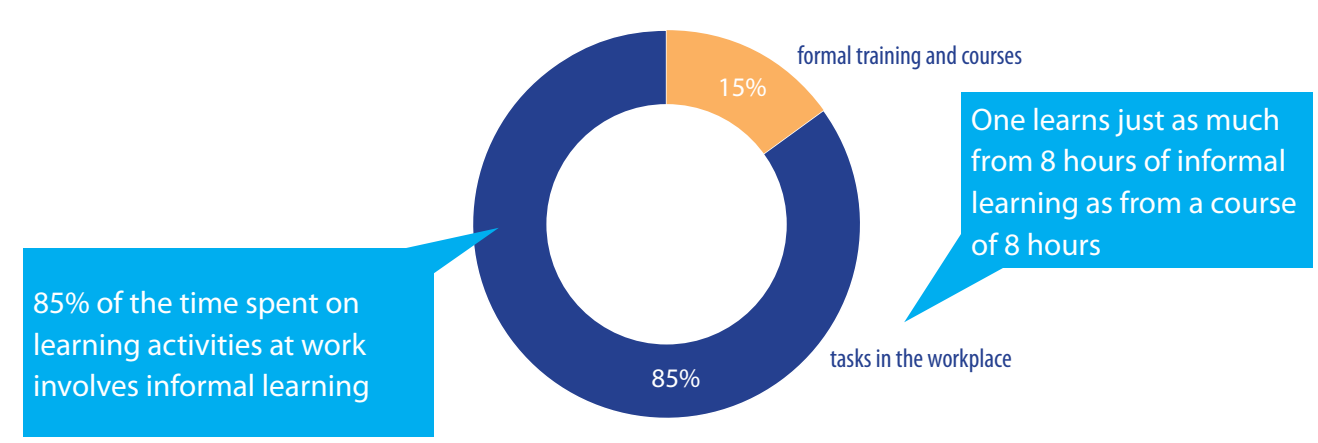

M COURSE PARTICIPATION IN THE PAST TWO YEARS

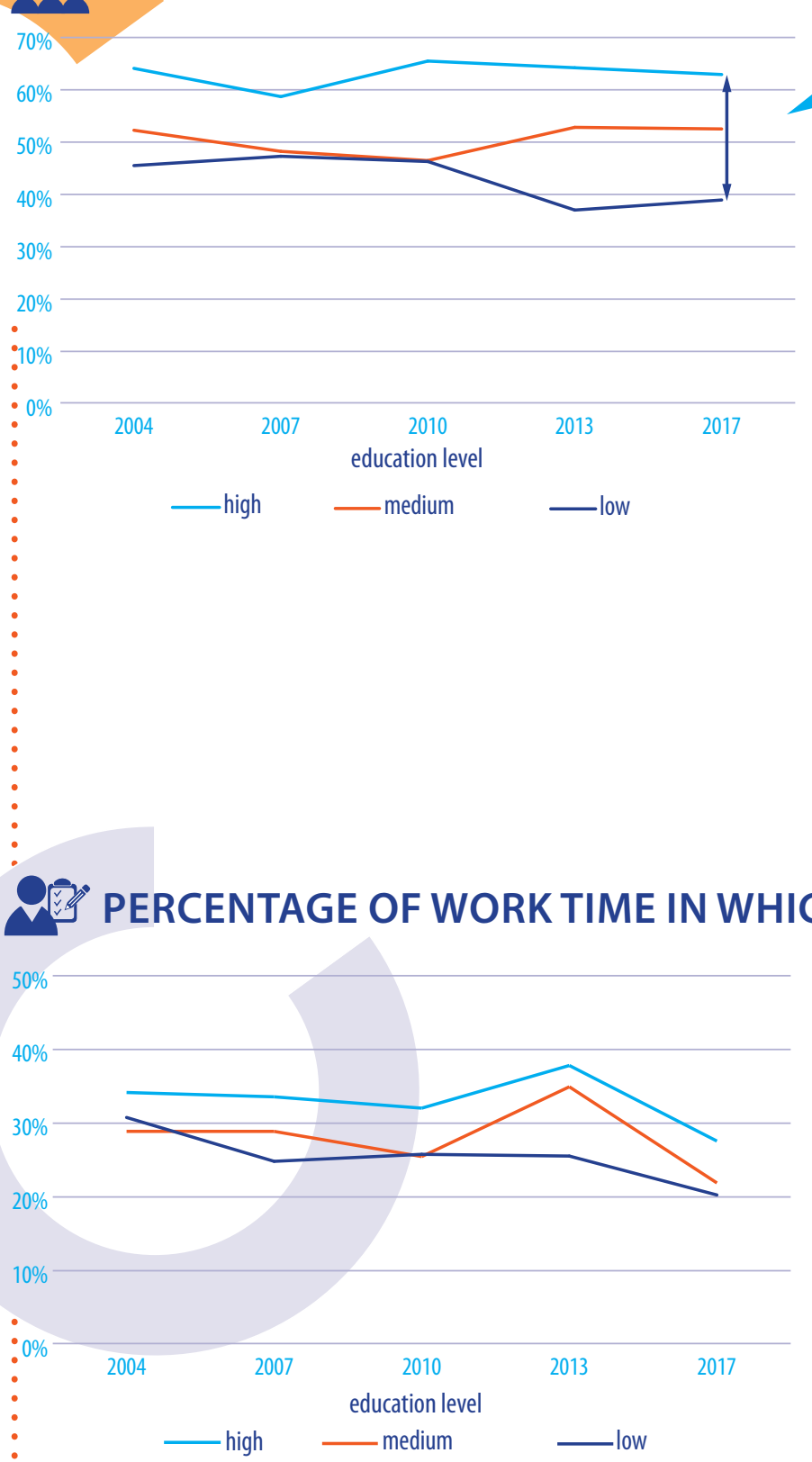

CH ONE LEARNS FROM TASKS one learns (=informal learning at work):

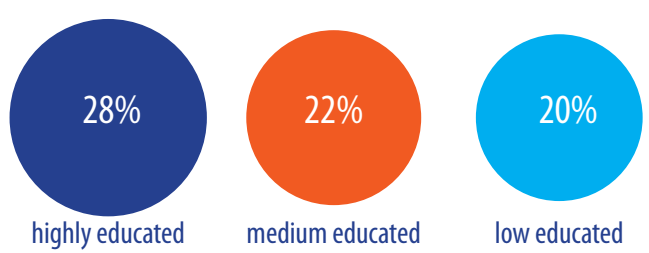

The amount of informal learning at work has decreased between 2004 and 2017.
A typical course:

- leads to a diploma/certificate $(79 \%)$

- relates to occupation-specific skills (54\%)

- is mandatory $(41 \%)$

- is undertaken to achieve career goals (36\%)

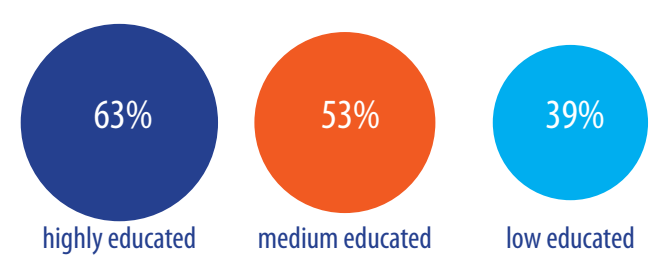

Percentage of work time in which one performs tasks from whic

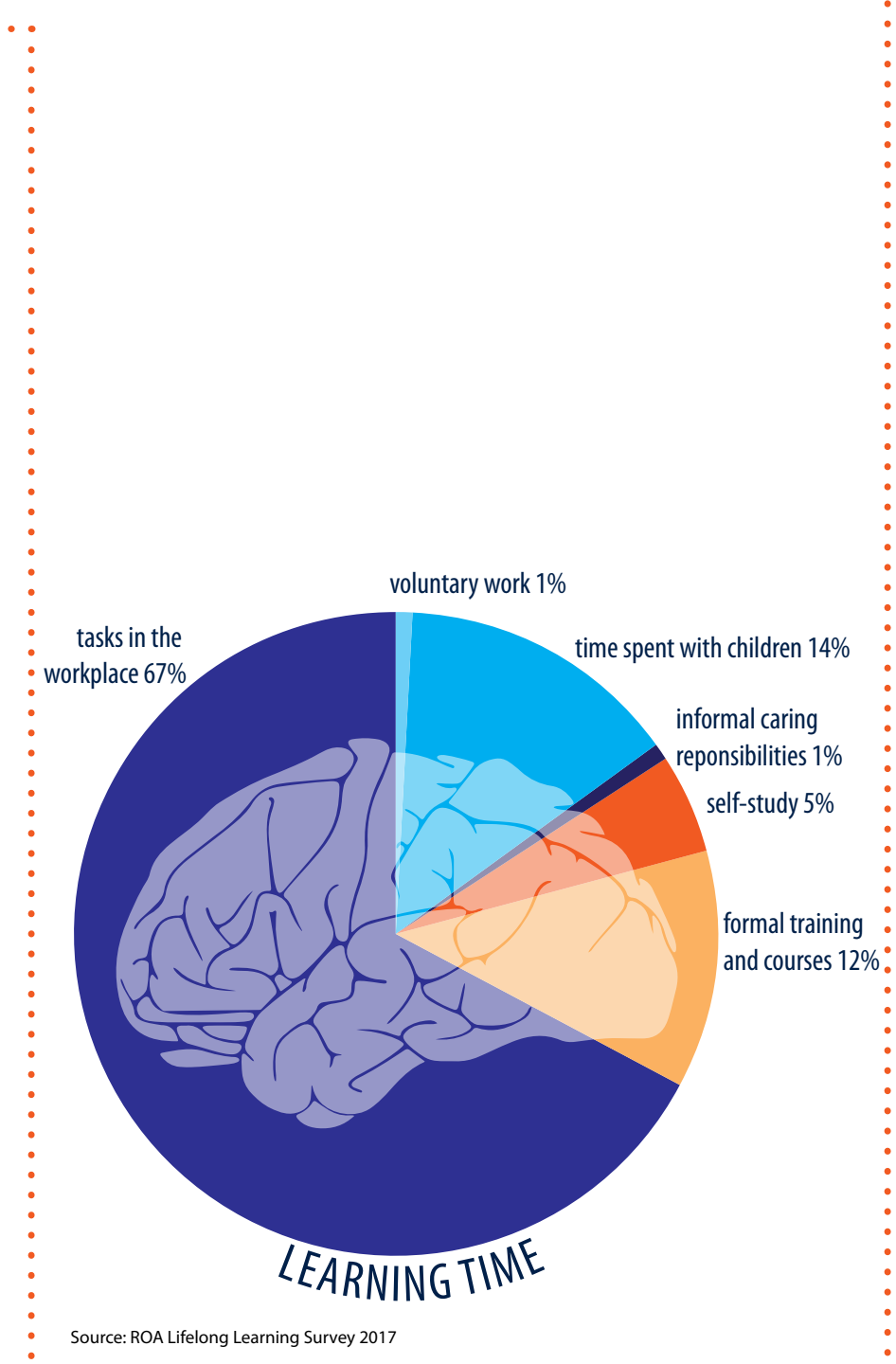

PERCENTAGE OF TIME IN WHICH ONE $\Leftrightarrow$ LEARNS FROM ACTIVITIES OUTSIDE OF WORK

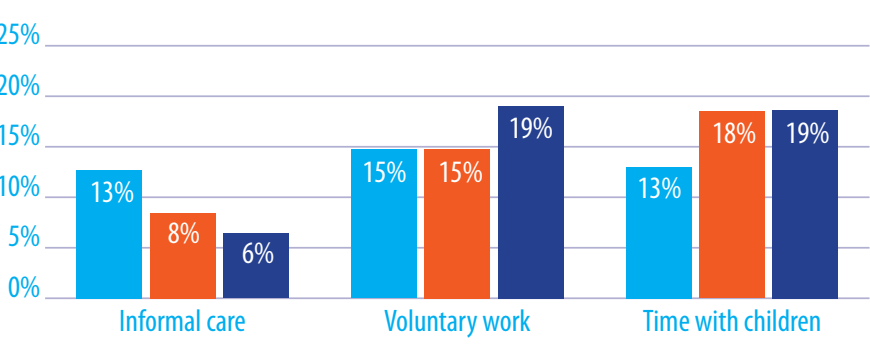

I low medium

Highly educated workers learn more from the time they spend with children and from doing community service than workers with a low level of education

Workers with a low level of education learn more from providing informal care than do highly educated workers 


\section{About the data:}

1. ROA monitors the formal and informal side of learning by the ROA Lifelong Learning Survey (ROA LLL).

2. The survey; which is based on a representative sample of the Dutch labour force; has been carried out in the years 2004, 2007, 2010, 2013 and 2017.

3. The data in this fact sheet relate to individuals who report doing paid work.

4. Time spent learning in the workplace and outside work is self-reported. For learning in the workplace we ask "what is the percentage of the working time you spend on tasks from which you can learn?" and relate the answers to the number of hours worked. For each reported activity outside work (e.g., voluntary work) we ask for the number of hours spent on that activity and "what is the percentage of that time you spend on tasks from which you can learn?"

5. This version of the fact sheet is a revised version of the fact sheet that was published in July 2017.

6. For more information on the project download ROA Lifelong Learning Project.

\section{Contacts:}

Didier Fouarge d.fouarge@maastrichtuniversity.nl

Andries de Grip a.degrip@maastrichtuniversity.nl

Research Centre for Education and the Labour Market

\section{P.O. Box 616}

6200 MD Maastricht

$\mathrm{T}+31433883647$

$\mathrm{F}+31433884914$

secretary-roa-sbe@maastrichtuniversity.nl

www.roa.nl

Maastricht University

School of Business and Economics 